\title{
“THE LAUGHING PHILOSOPHER": Whitman's Comic Repose
}

\author{
George B. Hutchinson
}

IN THE I88os, when Whitman's international reputation grew even as his poetry declined, he faced the problem of accommodating himself-and his poetic self-image - to loss of mobility and the decline of his health. He faced the challenge of old age and infirmity by "reposing" - maintaining emotional stability, conserving physical strength, and developing his role as "good gray poet." Today, scholars take essentially two points of view concerning Whitman's identity in old age. Many believe that he had finally merged the "mask" and the "man," that his serenity was "real." Others emphasize that he was sly and secretive, that he was "playing games" with his disciples, pretending to take them into his confidence while using them for ulterior purposes. ${ }^{1}$ Both interpretations are partially accurate, but both rest upon outmoded assumptions - rooted in Cartesian thought-about the nature of the self and the "self-protective" practices of people in the final stage of life. Partly because of these assumptions, our understanding of "the later Whitman" remains inadequate. In fact, so far no scholar has carefully investigated either the cultural resources or the profound contradictions involved in the poet's final "re-pose."

If, as scholars claim in a variety of disciplines today, every self is a symbolic construct, a sort of "fiction" or mask giving coherence to one's life, then it seems likely that we shape our selves-or play our "parts" in life-according to narrative and dramatic conventions absorbed consciously and unconsciously from our cultural milieu. For a man whose entire career was dependent upon a literary "self-making" and essentially a "divine comedy" of democratic identity, this phenomenon would be particularly significant. Moreover, anxieties about self-integration and self-justification become particularly acute in old age, as people strive to read the "meaning" of their lives in their personal histories. This meaning-even the integrity of the self as such-depends upon a larger, transcendent matrix of "meaning" that provides the terms within which the self can be known. Nearing the end of his life, Whitman struggled for a final integration of identity which, while linked to historical processes, could nonetheless be relied on to weather the shifting tides of history through unity with a transcendent process, the "flux and flow" of the universe. Fending off the twin threats of self-disintegration 
posed by old age and by America's betrayals of the creed he thought the Civil War had actualized, Whitman in his later years enacted a "comic re-pose" beholden to a western tradition of comedy and a stoic ethos of "playing one's part" in Nature's cosmic drama. Horace Traubel's With Walt Whitman in Camden is the best record we have of the poet's final act. ${ }^{2}$

The most important cultural resource Whitman drew upon to shape his identity in old age was Stoicism, a philosophy with which he had had long acquaintance. Gay Wilson Allen, C. E. Pulos, and Sholom J. Kahn have previously discussed Whitman's attraction to the Stoic Epictetus, but their essays concern chiefly the poet's early years. ${ }^{3}$ In the final decade of his life, Whitman returned to the Encheiridion frequently for support in his daily affliction, as he attested to Horace Traubel: "I like to think it over and over and over again with Epictetus-I have often said it to Doctor Bucke and to you, too-'What is good for thee, O Nature, is good for me!' That is the foundation on which I build-it is the source of my great peace" (WWWC, 1:423). Although Whitman had known of Epictetus in his youth, the volume he was reading in the years of Traubel's conversations with him had been given him by the translator, T. W. H. Rolleston, in 1881. Traubel often found him reading it and points out that the poet quoted from it frequently in conversation, "though never literally-always rather in substance" (1:207). Whitman once told him, "This book has become in a sense sacred, precious, to me: I have had it about me so long-lived with it in terms of such familiarity" (3:253). The poet's notations in this copy, according to William White, indicate that by the late 1880s Whitman considered Epictetus one of the greatest of all writers. ${ }^{4}$ In With Walt Whitman in Camden, the poet paraphrases the Encheiridion repeatedly, and we find Epictetus's statements showing up in his later prose works, as well. One might go so far as to say that what Emerson and Carlyle had been to him in the 1850s, Epictetus was after the Civil War, and especially in the 1880 s.

It would be difficult to imagine a philosophy better suited to Whitman's situation in old age than the Stoicism of the Encheiridion, which appeals powerfully to invalids and to those who face calumny, vilification, and death. Stoicism is, moreover, a most "cautious" philosophy in the sense that Whitman used that term when he boasted to visitors in Camden of his bumps - the phrenologists having rated him high in "caution." The philosopher, according to Epictetus, "goes about with the caution of convalescents, fearing to move the parts that are settling together before they have taken hold"; "he has taken out of himself all desire, and has transferred his aversion solely to things contrary to Nature which depend upon ourselves. He attempts nothing, except lightly and indifferently. If he is thought foolish or unlearned, he is not concerned. In one word, he watches himself as he would a treacherous 
enemy" (XLVIII). Concerning his reputation as well as his health and emotions, the later Whitman was a most Stoical convalescent. Conserving energy for Traubel's visits, he would nap every evening before the disciple's arrival and keep a close watch on emotional extremes: "I have to subject all my rebellious moods to the necessities of my corporeal self" (WWWC, 4:89). Husbanding his strength for those activities most directly related to his life's work, Whitman also kept a sharp eye on himself for any signs betraying dissatisfaction with his condition. In his letters as in his talks with Traubel, he preferred not to discuss his discomfort or his boredom, which is remarkable in view of the suffering we know he experienced. He would usually talk briefly of his poor health or low spirits only when Traubel, who always inquired on the subject, first arrived and they exchanged greetings. Whitman would quickly change the subject, unless he had been having a good day and could share his cheer.

As he struggled to suppress tendencies to depression brought on by physical confinement and infirmity, the poet destroyed photographs which he thought portrayed him in a "glum" mood. Referring to a recent portrait, he asks Traubel in one instance if his expression looks "glum - sickish - painful. . . . I hate to think of myself as pensive, despondent, melancholy. How is it? .. . Does it look unkind? No man has any excuse for looking morose or cruel: he should do better." Whitman might let Traubel keep the picture, "but does it look glum? That is so important to me: to not look downcastcloud up things. ... If you should ever use this portrait in any way - for this, that - be sure to say Walt Whitman was not a glum man despite his photographers" (3:378).

Implicit in Whitman's worry about "glumness" is the difficulty he was having in playing his role. This difficulty caused him to doubt his late poetry, to fear that he had let "morbidity" creep into his work at the last. "I am convinced all has forged forward from a poetic background-out of appropriate, deepest poetic seeing, emotionality-uttered in a setting of genuine sympathy: but whether here at last comes morbidity, introspection-forbidden, forbidding appearances - in that is the rub" $(6: 281)$. Hence he allowed his late poems to remain only in the "annexes" of Leaves of Grass.

When he expressed his concern to Traubel one day, the latter, paraphrasing chapter nine of the Encheiridion (which Whitman had loaned him with fervent recommendations), responded that death and old age "are only disease when the observer makes them so." Whitman seconded, "So it seems to me: and I think it is in such a conviction I shall abide. I never forget Mrs. Gilchrist's solicitude-and she was one of the [a]cutest women ever born ... her solicitude in fear-dread-that I would go off into pensivity. She would say, What has Walt Whitman to do with sunsets: I cannot conceive of him having anything to do with disease, old age, pain, invalidism, sunsets, sitting in an old cane chair - or housed in any way - or the like" (6:281). The statement reflects a complexly ironic self-awareness as well as the importance of the Stoic 
attitude for helping Whitman bridge the way from ruddy health to pale senescence. As he uttered his reminiscence, Whitman was not only "housed" but confined to his house in Camden, so battered by disease that he rarely had the will to venture out; moreover, he was doubtless sitting in the over-sized cane chair given him by the Donaldson family, and one of his meditative pastimes was to watch the sunset through his window in the evening. $\mathrm{He}$ always liked to close his own blinds after sundown. Hence, in remembering Mrs. Gilchrist's concern, Whitman addressed a situational irony due not simply to the involuntary effects of his infirmity but to choices he made, habits he enjoyed, as well. His attitude to this irony was Stoical rather than tragic. After all, sitting in an old cane chair, infirm and often in pain, religiously observing the sunsets, might not be so bad-it all depended upon the attitude of the observer.

Whitman defended himself against the anxieties expressed by Mrs. Gilchrist by portraying old age and invalidism, sunsets and ebbing tides, in a transcendent manner harmonizing the "half-paralytic" with the "yawper" of his earlier years. Both ethical and symbolic resources of his early prose and poetry aided him in his task. The Stoic route of conforming the will to "nature" as a means of transcending infirmity-reflected indirectly by the late poems and Specimen Days (1882), which contains more direct observation of nature than any of Whitman's earlier work-became a meditative discipline for Whitman. It was through such discipline that he was able to develop the apparent serenity and equanimity that so struck his visitors, the Stoical dignity of his final years. "In my periods of trouble-when I am sleepless-lie awake thinking, thinking, of things I ought not to think about at all -am flustrated [sic]-worried. Then I recover by centering all attention on the starry system - the orbs, globes - the vast spaces - the perpetual, perpetual, perpetual flux and flow-method, inevitability, dependability of the cosmos. It excites wonder, reverence, composure-I am always rendered back to myself" (5:434).

What is the "self" to which the poet is rendered back, if not a symbol of identity through which he projects his life as an integral whole and binds it to a cosmic schema? Whitman's statement agrees with the Stoic physics, derived from Heraclitus, that sees the world as being in continual flux and transformation, but impelled in an inevitable cyclical process of creation and dissolution. Within this process, the soul is essentially immortal and at the same time physically involved in the "flux and flow" of the cosmos. It remains for each of us to put our will in harmony with the "method" of that cosmos. Whereas a younger Whitman had found in the starry systems a stimulus to "dilation," intimating one's passage through successive "circles" of identity in an endless progression and development, the older Whitman reads in them something closer to Marcus Aurelius's Stoic reassurance that, though the fate of the soul after death cannot be known, "fluxes and flows perpetually renew the world" (quoted in Allen, "Whitman and Stoicism," 56). 
This was not, of course, a new discovery, but Whitman accorded it a new centrality in his work. As he had reconceived who he was, his symbolic world had been subtly altered.

In "Sands at Seventy" images of the stars and of the "flux and flow" of tides predominate. In fact, the tide becomes a more dominant symbol in this group and in Leaves of Grass as a whole than the more politically and socially significant leaf of grass (which dominated Whitman's poetry until after the Civil War) and in poem after poem Whitman gives the symbol as much "suggestiveness" as he can, connecting it not only with the ocean but with sunset and the cyclical procession of stars-all reminders of the eternal, "convective" law in which human destiny forms but a "droplet" or a "wave."

Then last of all, caught from these shores, this hill, Of you $\mathrm{O}$ tides, the mystic human meaning:

Only by law of you, your swell and ebb, enclosing me the same, The brain that shapes, the voice that chants this song. ${ }^{5}$

Whitman's poems become, in "Sands at Seventy," not "leaves" so much as "undulations," and he sees himself as merely one particle of the great flux. True, he had come close to a similar stance in "Out of the Cradle" (1859-60) and "As I Ebb'd With the Ocean of Life" (1860). The tides had always been important for Whitman, but never so important as they became in old age. ${ }^{6}$

The wave or tide even buoyed up the ostensible universe, "carrying" the cosmos toward its mysterious destination: "What subtle indirection and significance in you? what clue to all in you? what fluid, vast identity, / Holding the universe with all its parts as one-as sailing in a ship?" ( $L G$, "You Tides With Ceaseless Swell," 514.6-7). Whitman continually referred to his Mickle Street room as a ship's cabin, flooded with a "sea of paper" -indeed, his visitors often adopted the same terminology. One visitor claimed his large cane chair might have been made with a ship's spars. Not only do such details indicate how thoroughly Whitman, like the Stoics, retained the analogy between microcosm and macrocosm, the self and the "cosmos" ("the universe with all its parts as one-as sailing in a ship"), but they indicate how habitually he thought of his surroundings and his own life in theatrical terms, as if he were playing a part in some profound and mysterious drama.

In the symbolism of tides, developed out of an important symbolic complex of his earlier work, Whitman had found a strategy for exploring comic transcendence in passivity. "Sands at Seventy" - which Whitman defended as a "natural" outgrowth of his earlier texts - was to be the expression of the ideal old man of America, not going out in a "blaze of glory" but remaining true to himself as he feels his life "tapering off" (3:462).

It is important to recognize that Whitman deliberately chose "the quiet, the reposeful method: not hastily, not obstinately from any stultifying motive, but after long and long weighing and considering" (3:462). A role-taking 
process took shape in a scenario involving conscious choice, Whitman's relations with the world around him, and his physical decline. The poems both emerged from this process and helped Whitman "direct" it. As Gay Wilson Allen has argued, Whitman "strove assiduously to form his actual character and personality on the pattern of his literary ideal,"7 but that ideal itself developed in a dialectic with the poet's social and even physical world (including his somatic condition). We find reciprocal influences between the poet's life and the images projected by the poems, the prose, the friends and disciples, and Bucke's biography-a kind of identity-creating dialectic between "art" and "experience." The dying Whitman was to be even more transcendently comic than the poet in his prime; to this project he bent all his emotional and intellectual energy.

He knew, of course, that his essentially comic faith distinguished him from most Stoics, whose "indifference" to the affairs of this world exceeded his own, and who certainly would have denounced the indecorum of his early poems. However, the later Stoics, to whom Whitman was chiefly indebted, came close to sharing his sense of a "divine comedy." For them, according to R. M. Wenley, "The grim, doubtful figure of Fate assumed the kindlier lineaments of Providence, a spirit endued with forethought, working advisedly within human estimate of righteousness." ${ }^{8}$ Equilibrium is achieved in the final clusters and annexes of Whitman's "Deathbed edition" not by the cathartic and ennobling sacrifice of the hero, nor by the indifference of the early Stoics, but by fundamentally comic intimations of immortality. In the end Whitman was still being buoyed up by a faith he could not explain. $\mathrm{He}$ occupied the narrow space between late Stoic faith in nature and the mythos of comedy. Christopher Fry's definition of comedy is appropriate here: "Comedy is an escape, not from truth but from despair: a narrow escape into faith. It believes in a universal cause for delight, even though knowledge of the cause is always twitched away from under us, which leaves us to rest on our own buoyancy. ... In tragedy we suffer pain; in comedy pain is a fool, suffered gladly.... [Comedy] says, in effect, that, groaning as we may be, we move in the figure of a dance, and, so moving, we trace the outline of the mystery."9 Regarding the later Whitman as a comic thinker, we remember his fondness for the 1887 portrait by Fox which he named "The Laughing Philosopher" and sent to Tennyson. ${ }^{10}$ And that fascinating dance, With Walt Whitman in Camden, has the virtue of displaying, along with the garrulousness and ill-health, the endless and vivifying wit of the old man. ${ }^{11}$

\section{II}

In the part Whitman imagined himself playing, a Stoic attitude toward critical abuse was just as important as the acceptance of physical suffering. Whitman worked diligently throughout his career to develop an "immense bufferism" against critical attack-a Stoical attitude he later claimed as a 
"natural endowment." Traubel, however, occasionally had to bring the poet back to nature, checking flashes of resentment. In a notebook of 1868-70, Whitman outlines the attributes of a "superb calm character," paraphrasing Epictetus. According to the philosopher, the abuser does not affront us, but rather our attitude toward him; we should recognize that the critic speaks from an impression that is right to him, and that if he judges falsely then only he is hurt. ${ }^{12}$ Whitman repeatedly tells Traubel (except when he "forgets himself") that opposition to his message does not bother him; he does not blame the critics for their opinions, for why shouldn't they criticize him? They were merely doing what they thought was best, just as he was; and after all, "their denial may in the end be confirmed" (WWWC, 2:135; see also 1:251-253). He would not quarrel with the "Playwright": "this conflict-this continual pushing, nagging, discussing, - is no doubt necessary-I do not worry over it. Abstain not from physical reasons alone but from other reasons-see these circumstances as inherencies, inevitabilities - not only not to be avoided but not desirable to be avoided" ( $W W W C, 5: 446)$. The poet, of course, never inhibited his followers from entering the fray and striking back against the enemy, and he enjoyed drawing attention to the battle. However, like Socrates in Plato's Symposium, he was not cast to praise his own views or to defend himself from attack. Epictetus's advice helps account for the fact that the later Whitman allowed the disciples to extol his prophetic significanceundoubtedly enjoyed their adulation-even though he refrained from overtly pre-occupying himself with that significance.

The flattery of friends, however, could be as dangerous as the attacks of detractors according to the Stoic philosopher, and Whitman was careful to accept the "gush" of his admirers with apparent equanimity. "We must make the best of the good words of our friends," he claimed, amused by attempts to establish Walt Whitman societies. While complaining to his nurse, Eddie Wilkins, about the excesses of the seventieth birthday celebration in his honor, he told the hosts how much he had enjoyed it; and to the pamphlet commemorating it he appended a newspaper report of the party, to which he had added on his own, "he [Whitman] was averse to the public dinner at the outset, but said he should 'let the boys have their own way." "13 The poet thus enjoyed the flattery, publicity, and financial benefits while preserving his image of imperturbability. These celebrations, all male and full of lengthy disquisitions or dialogues, had a distinctly Greek flavor. ${ }^{14}$ Perhaps Whitman remembered Epictetus's advice on how to accept pleasant "externals" as if one were at a banquet or "feast": "Is some dish brought to you? Then put forth your hand and help yourself in seemly fashion. Does it pass you by? Then do not hold it back. Has it not yet come to you? Then do not stretch out for it at a distance, but wait till it is at your hand" (XV). When plans for a seventy-first birthday celebration came up, Whitman did not object but humorously admitted to Traubel, "My fear is a deluge of soft soap-that I may go down in the flood" (WWWC, 6:319). Subtly indicated here is the fear of "losing him- 
self," falling out of character rather than staying buoyed up on the "fluxes and flows." Whitman, perhaps, was haunted by a spectre of his own bad faith, the awakening of those desires he was trying to suppress.

By the time such celebrations were taking place-putting the poet almost literally on stage and testing his Stoicism in the acceptance of adulationWhitman had come to believe nature had cast him in the role of the prophet rejected in his own time and country. The playing of this role, and Whitman's struggle to be consistent in it, provides another unifying element of With Walt Whitman in Camden, perhaps the dominant one. Repeatedly referring to the struggle of Leaves of Grass for recognition as a play, a wrestling match, or a war for "the good old cause" (all frequent metaphors in Stoicism), he considered its history the most important thing for Traubel to pass on. Hence we find the first few volumes of With Walt Whitman in Camden full of letters and reviews relevant to the reception of Leaves of Grass. Several scholars have pointed out how Whitman exaggerated the critics' neglect of him - a fact of which even Traubel was aware. ${ }^{15}$ In the late editions of his poems and in Bucke's biography Whitman insisted upon publishing negative reviews of his work, and in the early 1870s he encouraged friends abroad to mention in critical articles the abuse he received from the American critical establishment. To Edward Dowden, for example, he wrote, "I say I think the statement of these things proper and even indispensable to any complete foreign criticism of my poems. True, I take the whole matter very coolly"which, of course, was a half-truth at best (WWWC, 1:320). In letters to Rossetti, as well, he tried to direct a foreign publicity program which exaggerated his ostracism in the United States; and in a letter to Rudolph Schmidt (a German translator of his poems) he said that comments about his persecution and damnation in America were "in truth . . . a necessary part of any complete criticism" of his work (WWWC, 1:407).

Such a puzzling statement suggests that Whitman regarded study of the social scene within which he worked as indispensable to the interpretation of his work itself. He had his thoughts on a drama extending outside the covers of Leaves of Grass, and his interpretation of that drama vitally supported his very view of who he was. The letters to Dowden and Schmidt date from the most depressing period of Whitman's life, the early to mid-1870s, but Whitman passed them on to Traubel with the intention of helping illustrate the struggle he had been through, which he rather slowly recognized as having abated by the last three years of his life. When Traubel asked if he had not over-emphasized the American ostracism, Whitman was reluctant to concede, insisting that he had been rejected in his own country $(4: 61-62 ; 2: 210-$ $212,220)$. Pushed further, he could only say that he must have lost some of the negative reviews he had collected, since most of the ones Traubel saw were favorable. What is astonishing is that Whitman gave his "historian" papers supposedly proving the "establishment's" rejection of his work but actually indicating the opposite! Scholars commonly might attribute such "fail- 
ure of memory" to a "senility" of old age, but I suspect that most influential was the comic narrative Whitman had adopted as central to his identity and dictating his role-playing process. Failures of memory are, we well know, frequently means of self-defense. Traubel had to "train" him to read the letters accurately, for the narrative to which Whitman was conforming his life affected his interpretation of his past.

Indeed, Whitman had come to believe that widespread acceptance would have either ruined him or been a sign that he had "gone off on a false scent" (1:435-436; 6:340). If, as he believed, American literary criticism still followed "feudalistic" Old World models, then the first truly "American" poet would face the scorn of the establishment - unless they found a way of "taming" him, domesticating him to European tradition, a tendency Whitman guarded against with provocative poses and gestures against "literary" artistry. Having caught the "full fire" of the enemy in his prime, by the 1880s, when testaments of acceptance began steadily mounting, Whitman came to rejoice in the "stormy early life" of the Leaves: "Nothing could make up for the loss of this -it was a priceless privilege. Ease, comfort, acceptation, would have ruined us" (6:340). Whitman's sense of the comic significance of his final acceptance is clear: "Are we like to become popular in our old agein our retirement from the stage? Who knows the issue of all this? After all that is gone before-the abuse, defamation-unknowing hatred.... But ... do you turn it over well - take its full measure-for the day may come when you if not I will need to record all the details of this story" (6:378). Elsewhere he sees through the comic filter how misfortune is transmuted into fortune: "Now, in these late days, as I look back upon the past, I can see that, in a sense, my misfortunes have been my fortunes - that it must have been altogether right for me to have travelled a rough, hard road-so to be tested, at last secured!" (5:263).

By exaggerating his conflict with the literary establishment and thus the unexpectedness of his final triumph, Whitman emphasized the specifically comic sort of narrative he had tried to live out. As a turn in fortune-following the dark months of the early 1870s and the loss of that robust health which had been so important to his earlier identity-elevated him as catalyst of a new social movement, he fit the sort of comic heroic mythos Northrop Frye defines in Anatomy of Criticism. In this archetypal pattern, the protagonist faces apparently insurmountable obstacles (an "older man" or other "authority" figure representing "law" or "establishment") which he defeats through a fortunate twist in the plot that allows him to become the center of a new, vaguely defined social configuration. The audience, moreover, as well as all of the characters involved in the action-even the "enemy" - are invited to be part of the new society. ${ }^{16}$

We need not accept a doctrine of "archetypes" to believe that Whitman was (perhaps subconsciously) acting out a classic comic plot pattern and encouraging his selected historian to represent it as such. To what extent the 
act was conscious deception is impossible to determine, since his "self" cannot be extricated from the symbolic, rhetorical system through which he both projected and interpreted it. If comedy (as Whitman had absorbed it) typically dramatizes a separation of perfect lovers by an impostor or an "established" authority figure who is finally defeated and assimilated into the new society centering upon the re-united lovers, we see the scenario reenacted in Whitman's relation to his reader and "lover," thwarted for so long by established political, sexual, and critical bans. The conventions of comedy thus played a key role in the shaping of the "good gray poet's" later career. It is indeed circumstantially comic that the turn in Whitman's fortune owed so much to cultivated English men of letters, whose unexpected crusade for him-more comically still-was based in part upon a misconception he had nourished, probably himself believing in the misconception despite evidence in his own hands. Hence Whitman's reputation grew partly as a playing out of a mythos he had adopted to give coherence and meaning to his life.

\section{III}

Although Stoicism would have repressed the comic sensibility, there was much in the Stoic view of life as a play-and of one's personal identity as a dramatic role - that appealed deeply to Whitman while he was preparing to depart from the "stage." Significantly, Epictetus's Stoicism combined a view of life as theatre and role-playing (thus "active," willed) with a radical passivity before fate and the necessities of nature. Believing that "What is good for thee, O Nature, is good for me" prevented neither Epictetus nor Whitman from comparing life to stage drama. "Remember that you are an actor in a drama, of such a part as it may please the master to assign you, for a long time or for a little as he may choose. And if he will you to take the part of a poor man, or a cripple, or a ruler, or a private citizen, then may you act that part with grace! For to act well the part that is allotted to us, that indeed is ours to do, but to choose it is another's" (Epictetus, XVII). Who the "you" refers to here is as problematic as the identity of the "real" Walt Whitman.

Epictetus suggests a dual sense of identity-a self by nature caught in its destined role and another aspect of identity, a guardian spirit, "apart from the pulling and hauling," which transcends the role-playing process through consciousness of its obedience to Nature. The transcendent self, or "demon," which is aware of its unity with the cosmos, perceives the other self as object and thus allows personality adjustments. When changeful events, suffering, calumny, or fear of death threaten to upset one's passional equilibrium, consciousness of the transcendent "self" at one with Nature-the director of the play, so to speak-helps one to play the role that is demanded, within it to achieve spiritual freedom. "Nature," avows Whitman in "Good-Bye My Fancy," "seem'd to use me a long while-myself all well, able, strong and happy - to portray power, freedom, health. But after a while she seems to 
fancy, may-be I can see and understand it all better by being deprived of most of these."17 Just as his earlier poetry had grown out of his involvement in the life of his times, he would keep producing poems true to his own condition, right up to the end of his life. He does not express a conviction that his later work is particularly good, only that he must follow his "demon"-a demon he compared to Socrates'. If the later poems showed weakening powers, that was as it should be. The extent of Whitman's anxiety about playing his role well, however, indicates his emotional investment in the projected image, an investment which is obvious in With Walt Whitman in Camden more than anywhere else.

In "Good-Bye My Fancy," on which Whitman worked during the period of Traubel's visits, the poet refers to his volume of that title (which includes both prose and verse) as equivalent to "one of those little punctures or eyelets the actors possess in the theatre-curtains to look out upon 'the house'one brief, honest, living glance."18 In such a self-conscious statement, however, Whitman is in a sense, perhaps unwittingly, "playing" the role of the actor looking out of the "eye-let." Unavoidably, the "living glance" is staged. The same problem is even more starkly epitomized in the poem "Out from Behind This Mask," subtitled "(To Confront a Portrait)."

Out from behind this bending rough-cut mask,

These lights and shades, this drama of the whole,

This common curtain of the face contain'd in me for me, in you for you, in each for each,

(Tragedies, sorrows, laughter, tears $-\mathrm{O}$ heaven!

The passionate teeming plays this curtain hid!) $(L G, 381-382.1-5)$

If the physical face itself is a mask, a "curtain" hiding "passionate plays," then what is the self besides a role? And how can one have confidence in its "authenticity"? Significantly, theatrical metaphors abound in Whitman's conversation, and Traubel, often a nettling presence, felt the need occasionally to bring Whitman back to his part when passion threatened to make the poet "forget himself." The "Real" self, in Stoic terms, is a role; to play it well is to fulfill one's destiny as determined by Nature. Hence, although we are tempted to read With Walt Whitman in Camden as the record of an extraordinary confidence game, the game surely was not entirely "intentional" in a superficial sense, since Whitman was hypnotizing himself as well as others, trying to conform to the standards of behavior he had adopted as a way of fending off betrayal of his life's work. He had constantly to battle his own desires. And he had to contend with the possibility that even his personal identity was, in a sense, "unreal" - that it had no ground outside of interpretation if the faith that sustained it was false. This faith, in turn, depended upon America fulfilling her role in universal history.

The more Whitman tried to project an integral self, the more anxious he must have secretly become about its reality, since he was, after all, having to 
"live up" to the part-and since there was little in the contemporary social world to prove that his theory of America's destiny (and thus of his own role) was accurate. Hence the poem "Out From Behind this Mask," with its plays within plays. Hence an increasingly Stoical detachment conflicting with a continuing intensification of hope.

\section{IV}

Whitman's increasing dependence upon Stoic detachment reveals not only his subliminal anxiety about aging, but a growing alienation from the social world surrounding him. The "mood" or "attitude" of Stoicism usually gains force in historical periods when the individual is alienated from a social or cultural matrix, often because that matrix is breaking down or losing its authority -in the era of Zeno and Chrysippus, when the city-state was being absorbed into empires; in the era of Epictetus, when the Roman Senate had lost authority and Stoicism became a movement of protest against the tyrants; in the time of Marcus Aurelius, who saw his world nearing its end; in the late Renaissance of Shakespeare; and in the era preceding the Civil War of the United States. ${ }^{19}$ In such eras, the "self" faces insult after insult as its integrity is thrown in question by the dissolution of those forms which have previously supported its coherence and authority. This phenomenon on the social-historical plane is curiously paralleled on the psycho-social plane by the phenomenon of aging and its attendant anxieties, the imperatives for a final self-creation which might transcend insults to the body or betrayals of those long-held beliefs upon which large portions of one's "life story" may have been based. ${ }^{20}$ Aged people often withdraw from contemporary events to protect themselves, to grow old "with dignity."

Although he rarely betrayed his doubts directly, on occasion Whitman revealed his fears that his own life story was baseless: "I get very impatient some days - am a little resentful: sore, sore: wonder if it's all fair and squarewhether the scheme after all is not doubtful: then I go back: find my way back to my central thought again -my spinal conviction: I resent my resentment am ashamed of my questions. Oh! I feel how empty everything would seem if I was not full of this faith -if this faith did not overflow me: how useless all things would be if they led on to nothing but what we see-to nothing but what we appear to wind up in here" (3:316-317). "What we appear to wind up in" refers not simply to Whitman's personal condition, but, in the context of the conversation, to that of the nation as well. After all, Whitman believed the war had destroyed his health and that the success of his poetic experiment depended upon the success of the democratic experiment. If the nation did not seem to be moving in the right direction, he could only fall back upon a faith that might not be justified until some unspecified time in the future. The "something" to which all was leading, Whitman Stoically concluded, could not be known-should not be known. One must commit oneself to the 
tasks at hand, keeping faith in indefinite results. The poet would not bother about where all was tending for the moment - "it would only confuse matters: we can make our declaration about it, say our yes, then stop" (3:317).

In Hegel's view of the "consciousness" of the Stoic form, "whether on the throne or in chains, in the utter dependence of its individual existence, its aim is to be free, and to maintain that lifeless indifference which steadfastly withdraws from the bustle of existence, alike from being active as passive, into the simple essentiality of thought. . . . Stoicism is the freedom which always comes directly out of bondage and returns into the pure universality of thought."21 Whitman's bondage was paralysis; his hidden fear, that America might after all betray his faith in her despite the sacrifices of the Civil War which, he liked to think, had assured her self-realization once and for all. ${ }^{22}$

Whitman's belief in the war was as detached from contemporary social reality as was his Stoic attitude toward his physical condition. Both floated above the actual in the realm of "Nature's" fluxes and flows. In fact, he purposely avoided dwelling on the signs of social and economic injustice around him. Rather than contemplating current socio-economic transformations that belied his prophecies, Whitman reminisced continually about a past whose meaning he was "sure" of, and which promised fulfillment. To withdraw from current excitements was a pleasure, as he intimates in the opening of "A Backward Glance O'er Travel'd Roads," the preface to November Boughs which was composed during the period of the Camden conversations: "Perhaps the best of songs heard, or of any and all true love, or life's fairest episodes, or sailors', soldiers' trying scenes on land or sea, is the résumé of them, or any of them, long afterwards, looking at the actualities away back past, with all their practical excitations gone. How the soul loves to float amid such reminiscences!" ( $L G, 561)$. Whitman loses immersion in actual history-the buffeting of ocean storms, to borrow his own imagery-and turns to "floating" on a vision of the past, to reminiscence and interpretation which will help him "round out" his life and integrate it; in "A Backward Glance" he actually uses the metaphor of a ship returning to port after a long and trying voyage.

It is a commonplace that during this time his poetic forms became more conventional and even his identity less revolutionary as he fell into the role of sage, Stoic, "laughing philosopher." He moved from ecstaticism (his particular shamanistic brand of mysticism) to a comic Stoicism, which, rhetorically speaking, accomplished the same effect as ecstaticism vis-à-vis existential oppression. That is, both modes could give a sense of "ultimate identification" (Kenneth Burke's term) $)^{23}$ by binding one to the "cosmos." During the later years he played down the ecstaticism of the pre-war verse and emphasized instead a more philosophical identity with the universe. Similarly, the ecstatic quality virtually vanishes from his poems after "Passage to India," a work 
which fails as an ecstatic poem precisely because of the absence of active personal threat. ${ }^{24}$

Whitman had withdrawn from the contemporary social/historical world, from the actual crises which had largely precipitated his earlier ecstaticism. He admitted to Traubel that he was not trying to keep up with current events and ideological squabbles, had little interest in them. Centering his self-integration around the Civil War experience, to which he attributed both his salvation and his physical paralysis, he clung to his pre-war Jeffersonian-Jacksonian ideology and withdrew from situations in which the meaning of the past might be thrown in question. ${ }^{25}$ Paradoxically, Whitman's Stoic withdrawal served to buttress an emotional attachment to his earlier experiences and intellectual commitments. Thus his Stoicism could never be complete; he had to believe in American democracy, since the very self whose "freedom" from fear and bondage he was protecting through the Stoic attitude depended upon a belief in the nation. However, he could mask this contradiction in his thought with the belief that democracy was written into the processes of Nature, a belief which, as I have argued elsewhere, is central to his autobiography Specimen Days. ${ }^{26} \mathrm{He}$ could thus keep faith in democracy without fretting over its contemporary condition..$^{27}$ On the other hand, any hidden anxieties about the future of the nation would implicitly call in question his entire structure of belief.

Despite the apparent serenity of Whitman's later years, and despite his ever-repeated belief that democracy was now assured of its future, it is clear that this serenity and this belief were hard-won - that they masked a level of anxiety the poet perhaps could hardly admit to himself. People do not resort to Stoicism, after all, when they feel free of worry and fully confident in the fulfillment of their desires. The threats posed by old age and America's betrayal were countered by Stoic withdrawal of desire, reliance on "Nature," and the comic plot. Whitman affected to stand back and watch this plot be played out. But the withdrawal of desire could never really be accomplished-as, even if the role in life was recognized as such, desire inevitably was caught up in that role. Whitman could never be a thorough-going Stoic, as his attachment to the comic plot proves. He tried to mask his desire-not only from others, but from himself. One of our greatest poets of "democratic identity," Whitman in his final years struggled with the fundamental difficulties posed by secularization, fragmentation, and modernity-struggled to "keep his act together" within a world in which constant, rapid change threatens any stable matrices of meaning upon which a life story can be based. Since his time it has become no easier to grow old. ${ }^{28}$

The University of Tennessee, Knoxville 


\section{Notes}

1 Of course, these two points of view are not entirely contradictory; Whitman could be serene and radiant without believing he was a prophet. Edwin Haviland Miller, for example, holds that "the olympian detachment and the almost godlike radiance which Thomas Eakins captures in his magnificent portrait, and which observers repeatedly noted, were more than a pose: Whitman was at peace with himself" (Walt Whitman's Poetry [New York: New York University Press, 1968], 18). On the other hand, in his more recent introduction to the fourth volume of The Correspondence (New York: New York University Press, 1977), Miller sees Whitman as acquiescing in the prophet image insisted upon by disciples but being, himself, undeceived by this image (3). The latter interpretation generally adheres to that of Roger Asselineau, who says Whitman "succeeded in embodying the ideal of Olympian old age that he had always admired" but never succumbed to the idolatry that surrounded him (Walt Whitman: The Evolution of a Personality, [Cambridge: Harvard University Press, 1960], 264, 259-265). Virtually all the biographers agree on this, although some, like Gay Wilson Allen (The Solitary Singer, rev. ed. [New York: New York Univ. Press, 1967]) and Justin Kaplan (Walt Whitman: A Life [New York: Simon \& Schuster, 1980]) give more attention to the poet's "caginess" even while noting his apparent serenity. Leslie Fiedler's view is that, "By the time he had invented the Good Gray Poet, he had burned away all of himself that was not the image. . . . If this is a 'pose' or 'fraud,' it is not one which we can despise" ("Images of Walt Whitman," Leaves of Grass One Hundred Years After, ed. Milton Hindus [Stanford: Stanford University Press, 1955], 58).

2 Horace Traubel, With Walt Whitman in Camden, 6 vols.: 1 (Boston: Small, Maynard, 1906); 2 (New York: D. Appleton, 1908); 3 (New York: M. Kennerley, 1914); 4, ed. Sculley Bradley (Philadelphia: University of Pennsylvania Press, 1953); 5, ed. Gertrude Traubel (Carbondale: Southern Illinois University Press, 1964); 6, ed. Gertrude Traubel and William White (Carbondale: Southern Illinois University Press, 1982). Hereafter cited parenthetically in the text by volume and page number, identified when necessary by "WWWC."

3 Allen, "Walt Whitman and Stoicism," in Duane J. MacMillan, ed., The Stoic Strain in American Literature (Toronto: University of Toronto Press, 1979), 43-60; Pulos, "Whitman and Epictetus: The Stoical Element in Leaves of Grass," FEGP 55 (1956), 75-94; Sholom J. Kahn, "Whitman's Stoicism," Scripta Hierosolymitana: Studies in Western Literature 10 (1962), 146-175.

4 White, "Whitman's Copy of Epictetus' Encheiridion," Walt Whitman Review 8(1962), 95[96]. Whitman's copy of the "manual" is in the Library of Congress. I will be quoting from this volume, The Encheiridion of Epictetus, trans. T. W. H. Rolleston (London: Kegan Paul, Trench, 1881), citing passages by "chapter" number, since the translation is quite rare and the chapters are very brief. I would like to thank Kenneth $M$. Price for telling me he had seen Whitman's copy in the Library of Congress after I had been given to believe that it was lost. Thanks also are due to Peter Van Wingen at the Library of Congress for his help in locating the volume and sending me photocopies of the relevant pages.

5 "Then Last of All," in Leaves of Grass: Comprehensive Reader's Edition, ed. Harold W. Blodgett and Sculley Bradley (New York: New York University Press, 1965), 516. Further references to this edition of Leaves of Grass will be cited parenthetically in the text with the abbreviation " $L G$."

6 In his introduction to the fourth volume of the correspondence, E. H. Miller points out that Whitman's later letters often use "water imagery," references to "ebb tide" and so forth. Moreover, the poet spent the last days of his life on a water bed! (5).

7 Walt Whitman as Man, Poet and Legend (Carbondale: Southern Illinois University Press, 1961), 17. 
8 Stoicism and Its Influence (New York: Cooper Square, 1963), 104.

9 "Comedy," in Comedy: Meaning and Form, ed. Robert W. Corrigan (Scranton: Chandler, 1965), 15-16.

10 Whitman appropriates the "Laughing Philosopher" appellation from Democritus of Abdera, whose ethical ideal consisted of a harmonious cheerfulness.

11 Obviously the sort of "comedy" I have in mind here is not the same as the sort Richard Chase discovered in "Song of Myself" (Walt Whitman Reconsidered [New York: William Morrow, 1955], 58-82), nor what E. H. Miller has in mind when he argues that comedy disappears from Whitman's later works, along with eroticism and "braggadocio" (Whitman's Poetry, 221). It is true that "Comedy originates in the dynamics of tensions and often serves as a defense mechanism to shield its creator's disaffections" (221). However, the form of this comedy need not be the kind of boasting and erotic gamesmanship of the early Whitman; it can be the more stoical comedy of reliance upon "nature" to transmute misfortune into fortune. In Miller's view, Whitman did not "need" comedy at the end, because he was "serenely detached," "at peace with himself" (18). On the contrary, I would argue that his peacefulness and detachment were achieved as preemptive comic-stoic defenses of the self against the "realities" of infirmity, annihilation, and possible worldly failure.

12 See Notebooks and Unpublished Prose Manuscripts, ed. Edward F. Grier (New York: New York University Press, 1984), 2:886-890. This passage appears in the same series of notes in which Whitman counsels himself to "depress" his "adhesiveness" and avoid the excessive "perturbation" of his affection for Peter Doyle. He is paraphrasing Epictetus, XLII.

$13 W W W C$, 5:339. Comment to Wilkins reported in Thomas Donaldson, Walt Whitman, The Man (New York: Francis P. Harper, 1896), 101.

14 See the anonymous review of Whitman's seventy-first birthday celebration: "We cannot give a full report of this most remarkable talk and supper (which was curiously conversational and Greek-like)." It seems likely that Whitman wrote the piece. He quotes from it at length in "Good-Bye My Fancy," Prose Works 1892, ed. Floyd Stovall (New York: New York University Press, 1964), 2:686.

15 See especially E. H. Miller, "Introduction," in The Correspondence, 4:1; and Robert Scholnick, "Whitman and the Magazines: Some Documentary Evidence," American Literature 44 (1972), 222-246.

16 Anatomy of Criticism (Princeton: Princeton University Press, 1957), 163-186.

17 Prose Works 1892, 2:708.

18 Prose Works 1892, 2:678.

19 See Wenley on the contexts of Greek and Roman Stoicism. T. S. Eliot wrote concerning the importance of Seneca for Elizabethan drama: "In Elizabethan England we have conditions apparently utterly different from those of imperial Rome. But it was a period of dissolution and chaos; and in such a period any emotional attitude which seems to give a man something firm ... is early taken up." "It was natural that in a time like that of Elizabeth stoicism should appear. . . . Stoicism is the refuge for the individual in an indifferent or hostile world too big for him; it is the permanent substratum of a number of versions of cheering oneself up" ("Shakespeare and the Stoicism of Seneca," in Selected Essays [New York: Harcourt, Brace \& World, 1960], 112).

20 For the importance of "life review" to the aged, see especially Robert N. Butler's groundbreaking article, "The Life Review: An Interpretation of Reminiscence in the Aged," Psychiatry 26 (1963), 65-76. My approach to this phenomenon has also been shaped by Erik Erikson, particularly his Identity and the Life Cycle (1959; rpt. New York: Norton, 1977); and by Marc 
Kaminsky, "The Uses of Reminiscence: A Discussion of the Formative Literature," in The Uses of Reminiscence, ed. Marc Kaminsky (New York: Haworth, 1984), 137-156.

21 Phenomenology of Spirit, trans. A. V. Miller (Oxford: Clarendon Press, 1977), 121.

22 M. Wynn Thomas makes a related point at greater length in the final chapter of The Lunar Light of Whitman's Poetry (Cambridge, Mass.: Harvard University Press, 1987), 252-280.

23 A Rhetoric of Motives (Berkeley: University of California Press, 1969), 328-333.

24 See George B. Hutchinson, The Ecstatic Whitman (Columbus: Ohio State University Press, 1986), 170-182.

25 As he told Traubel, his faith "finally rest[ed] on the social unit - the unit of a home-say of one, 2 or 3 thousand a year -three thousand at highest. . . With it, individual liberty - not land, or anything whatever, in common-but homestead, fee simple, moderate possession, assured every man. That is where the politics of the time is all wrong - the stake of the manufacturer, millionaire, aristocrat, corporation on one hand, their men on the other" (5:22).

26 "Life Review and the Common World in Whitman's Specimen Days," South Atlantic Review 52 (1987), 3-23.

27 "Democratic Vistas" does not contradict this view, since the criticism in that essay is merely a prelude to the ultimate affirmation of American promise.

28 I would like to thank the Graduate School of The University of Tennessee, Knoxville, and the John C. Hodges Fund of the Department of English at the same institution for summer funding which helped support research for this article. 